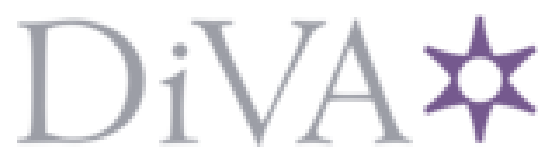

http://www.diva-portal.org

\title{
Postprint
}

This is the accepted version of a paper published in Nature. This paper has been peer-reviewed but does not include the final publisher proof-corrections or journal pagination.

Citation for the original published paper (version of record):

Gudasz, C., Bastviken, D., Steger, K., Premke, K., Sobek, S. et al. (2010)

Temperature-controlled organic carbon mineralization in lake sediments.

Nature, 466(7305): 478-481

http://dx.doi.org/10.1038/nature09186

Access to the published version may require subscription.

N.B. When citing this work, cite the original published paper.

Permanent link to this version:

http://urn.kb.se/resolve?urn=urn:nbn:se:uu:diva- 135652 


\section{Temperature-controlled organic carbon mineralization in lake sediments}

Cristian Gudasz*, David Bastviken**, Kristin Steger*, Katrin Premke*, Sebastian Sobek*, Lars

J. Tranvik*

*Dept. of Ecology and Evolution, Limnology, EBC, Uppsala University, Norbyvägen 18D,

SE-752 36 Uppsala, Sweden

**Dept. of Thematic Studies - Water and Environmental Studies, Linköping University, SE-

58662 Linköping, Sweden

Peatlands, soils, and the ocean floor are well-recognized sites of accumulation of organic carbon (OC), representing important global carbon sinks ${ }^{1,2}$. Although the annual burial of OC in lakes and reservoirs exceeds that of ocean sediments ${ }^{3}$, inland waters receive very limited attention as a component of the global carbon cycle ${ }^{4,5,6}$. Of the OC being deposited onto the sediments, a certain proportion will be mineralized, and the remainder will be buried over geological timescales. We investigated to what extent a warmer climate will affect OC mineralization and burial in lake sediments. Here we show that the mineralization of $\mathrm{OC}$ in lake sediment is strongly positively related to temperature, implying that increased water temperature leads to more mineralization and less burial of OC. For lakes in the boreal zone, assuming that OC delivery to the sediments will be similar to present-day conditions, we estimate that temperature increases according to latest scenarios presented by the Intergovernmental Panel on Climate Change ${ }^{7}$ result in a

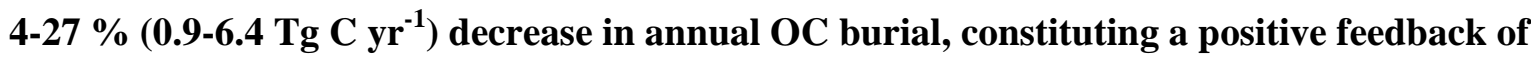
aquatic carbon release on climate. 
The sequestration of OC in the sediments of inland waters, both natural and man made $\mathrm{e}^{8,9,3,10,11}$, is comparable to or even higher than in marine sediments ${ }^{4}$ and soils ${ }^{12,13,14,15}$. Inland waters do not only bury OC, but are also active sites for the mineralization of considerable amounts of OC, originating from internal production or from the terrestrial environment ${ }^{4,5,16}$. The OC that reaches the lake sediment surface will partly be mineralized to $\mathrm{CO}_{2}$ or $\mathrm{CH}_{4}$ by heterotrophic microorganisms, and partly be buried in the sediments. The proportion of the OC buried (i.e., the ratio of OC burial per OC deposition onto the sediment surface) is termed the OC burial efficiency, while the fraction of the sediment OC that is lost through microbial processing is termed OC mineralization. As a consequence, the amount of OC that is eventually buried is a direct function of the burial efficiency ${ }^{17}$. The OC burial efficiency in lake sediments is related to oxygen exposure, but the effect of temperature on OC mineralization and burial remains unclear $^{17}$. Relationships between lake sediment mineralization and temperature proposed so far are subject to confounding factors such as lake depth, OC quality, and lake trophic state ${ }^{18,19}$. In view of anthropogenic global warming and the substantial amount of OC buried in inland water sediments, it is critical to elucidate how temperature affects burial efficiency, to allow assessment of the future role of lakes as carbon sinks.

The boreal region contains roughly $30 \%$ of the global lakes ${ }^{20,21}$ and is rich in $\mathrm{OC}^{22}$. Accordingly, boreal lake sediments contain $15 \%$ of the total carbon pool of the biome ${ }^{22}$. The Canadian boreal forest region alone could account for more than $10 \%$ of the global lake burial ${ }^{5}$. Northern latitudes, including the boreal zone, are expected to experience particularly severe warming ${ }^{7,23}$, suggesting that temperature-dependence of sediment OC burial may be of particular importance at these latitudes.

We assessed the relationship between sediment OC mineralization and temperature in a crosssystem survey of boreal lakes in central Sweden, and by compilation of published data from widely different lakes. We surveyed eight lakes with different trophic state and loading of terrestrial dissolved organic carbon (DOC) and total phosphorus (TP), enabling us to assess the relative importance of temperature vs. lake trophic conditions and sediment organic matter characteristics. Sediment mineralization was measured as dissolved inorganic carbon production 
in undisturbed sediment cores, sampled along a depth gradient within each lake. In addition to the field survey, we also did experimental incubations of lake sediment in the laboratory to test the temperature sensitivity of sediment mineralization in contrasting lakes.

Mineralization of OC in the boreal lake sediments was strongly positively correlated with temperature $\left(\mathrm{r}^{2}=0.61, \mathrm{P}<0.0001, \mathrm{n}=219\right)$ and weakly correlated with the TP concentration in the water $\left(r^{2}=0.14, P<0.001\right)$. There were statistically significant, but very weak relationships between OC mineralization and indicators of OC degradability such as C:N and C:P ratio of the sediment $\left(\mathrm{r}^{2}=0.027, \mathrm{P}=0.01, \mathrm{r}^{2}=0.028, \mathrm{P}=0.013\right)$. There was no correlation between sediment OC mineralization and measures of elemental composition of the sediment organic matter (C, N, P concentrations; $\mathrm{r}^{2}=0.002, \mathrm{P}=0.48 ; \mathrm{r}^{2}=0.007, \mathrm{P}=0.23 ; \mathrm{r}^{2}=0.005, \mathrm{P}=0.30$ respectively). A PLS (partial least square) regression of sediment OC mineralization against temperature, elemental composition of sediment organic matter (C:N, C:P ratio, C, N, P concentration), and TP concentration in the water column, explained a major fraction of the variance in the dataset $\left(\mathrm{R}^{2} \mathrm{Y}=0.66\right)$, and corroborated the dominant effect of temperature on OC mineralization in the sediment. Similarly, a multiple regression model predicted sediment OC mineralization from temperature (T) and total phosphorus concentration in the water column (TP W) (OC mineralization $=-75.03+0.34 * \log \mathrm{TP} \mathrm{W}+31.21 * \log \mathrm{T} ; \mathrm{F}(2,216)=193.67 ; \mathrm{P}<0.0001 ; \mathrm{n}=219)$, but explained only a slightly higher proportion of the variability in OC mineralization compared to a model with temperature alone $\left(r^{2}=0.64\right.$ vs. $\left.r^{2}=0.61\right)$. Lastly, we also compared the partial correlation coefficients of the model terms for temperature $\left(r_{\text {partial }}=0.76 ; n=219\right.$ : $\left.P<0.0001\right)$ and total phosphorus in the water column $\left(\mathrm{r}_{\text {partial }}=0.28 ; \mathrm{n}=219 ; \mathrm{P}<0.0001\right)$, suggesting a strong effect of $\mathrm{T}$ and a small, but significant effect of TP W on OC mineralization. Hence, OC mineralization rates were primarily explained by temperature, and the other studied variables were of subordinate importance.

We then added data of similar observations of temperature and sediment OC mineralization from a wide range of lakes that differ with respect to climate, productivity and OC source, based on a compilation of the published literature (Supplementary Notes). The combined data from the present study and the literature showed a positive correlation of sediment OC mineralization 
with temperature (Fig. 1a, $\mathrm{r}^{2}=0.43, \mathrm{P}<0.0001, \mathrm{n}=574$ ), suggesting that the regulation of OC mineralization by temperature is valid for sediments of widely different lakes.

Additional laboratory experiments on sediments from lakes with contrasting sediment types demonstrate a direct controlling effect of temperature on sediment OC mineralization (Fig. 1b). The studied lakes are very different in terms of organic matter source and productivity: terrestrial organic matter dominated Svarttjärn sediment, while Vallentunasjön sediment was dominated by algal debris (Supplementary Methods). The response to temperature was very similar for both kinds of sediments (Fig.1b), supporting that temperature, rather than any potentially co-varying factor, caused the strong positive relationship between OC mineralization and temperature observed in the larger set of data (Fig. 1a).

We also compiled data on long-term net accumulation of OC in lake sediments based on syntheses of data at global and regional scales as well as estimates in individual lakes/sediment cores. Comparison of these data with the sediment carbon mineralization estimates reported above, suggests that more than half of the OC that reaches the sediment is likely to be mineralized (Fig. 2). Sediment OC mineralization was on average 2.8 (median, 3.8) times higher than average global and regional estimates of long-term net accumulation of OC in lake sediments, and 5.1 (median, 6.4) times higher than long-term net accumulation determined from individual lakes or sediment cores. Thus, the estimated burial efficiency of about $20 \%$ is similar to the reported values of burial efficiency in lake sediments ${ }^{17}$. Hence, a large share of the OC deposited onto the sediments is mineralized, and, accordingly, a small change in mineralization (e.g., due to increased temperature) may result in a drastic change in OC burial efficiency. To assess how far global warming may affect accumulation of OC in sediments, we investigated the consequences of global warming scenarios for OC burial.

Based on the temperature - sediment mineralization relationship in Fig. 1a, we estimated the effect of temperature on the OC burial for boreal lakes under different warming scenarios ${ }^{7}$, assuming that the future deposition of OC to the lake bottoms will be similar to present-day conditions. Potential increase of OC delivery to the lake sediments could result in an increase in the amount of OC buried. However, the proportion of OC buried (i.e. the burial efficiency) will 
be reduced in a warmer climate due to a higher proportion of the sediment OC being mineralized. Even in cases of increased delivery of OC to the sediment due to climate change, there will not be a corresponding increase in OC burial, as rising temperatures will increase OC mineralization and thereby lower OC burial efficiency (for more information see Supplementary Methods and Supplementary Discussion). Our estimate is further based on the area of lake sediments expected to experience warming in direct proportion to increasing air temperatures via mixing of the water column. Different scenarios simulating a doubling in atmospheric $\mathrm{CO}_{2}{ }^{24,25}$, predict consistently higher lake surface water temperatures but somewhat variable response of bottom temperatures. These predictions have been confirmed by observations of strong surface water warming during the 2003 European heat wave ${ }^{26}$. About half of the total lake sediment area in the boreal zone has been estimated to be in contact with mixed surface water ${ }^{27}$, a value that is supported by observations in 88 lakes in boreal Canada ${ }^{28}$ and 25 lakes in boreal Sweden ${ }^{29}$. Hence, warmer air temperature will directly affect OC mineralization in about half of the sediment area.

The predicted increase in OC mineralization in sediments overlain by mixed water in response to temperature under the most likely warming scenarios (i.e., $\left.1.8-4^{\circ} \mathrm{C}\right)^{7}$, resulted in a decrease in

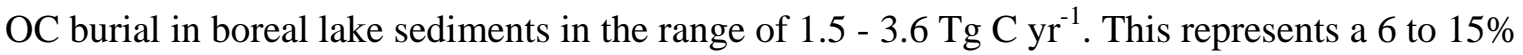
decrease in OC burial in lake sediments over the boreal zone (Fig. 3). Applying the likely temperature range scenarios (i.e., 1.1-6.4 $\left.{ }^{\circ} \mathrm{C}\right)^{7}$, the response of sediment mineralization to

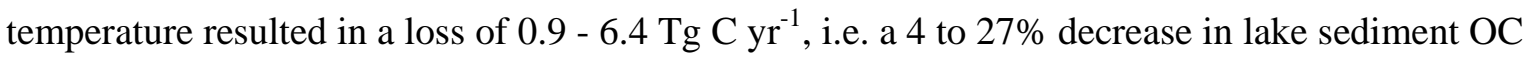
burial for the entire boreal zone (Fig. 3). This indicates that at the end of the $21^{\text {st }}$ century ${ }^{7}$, the strong temperature dependence of sediment OC mineralization will result in a significant decrease in the burial of OC in boreal lakes, and thereby in a concomitant increase in greenhouse gas emissions from lake sediments. This is analogous with the recently discovered positive feedback on global warming caused by increased mineralization in peatlands of the Northern Hemisphere $^{30}$.

After peatlands, lake sediments are the second largest pool of OC in the boreal zone ${ }^{20}$ and changes in the accumulation or mineralization of carbon in the sediments may affect the 
greenhouse gas balance of the landscape. Here we show that temperature controls OC burial efficiency in lake sediments. The projected change in temperature can be expected to significantly reduce lake OC burial and increase greenhouse gas emissions from lakes in the boreal zone, and probably also elsewhere.

\section{Methods Summary}

We surveyed eight lakes in Central Sweden with different trophic status and receiving different amounts of terrestrial DOC (Supplementary Table 1). The lakes were sampled four times on a seasonal basis, between April 2007 and February 2008. Some of the lakes were thermally stratified during summer. However, our study includes only sediments overlain by oxygenated waters. Within each lake, intact sediment cores were sampled along a depth gradient and incubated in situ or at in situ temperatures. Incubations were carried out in the dark and start and end water samples were collected and analyzed for the DIC (dissolved inorganic carbon) and methane concentration. Surface water samples were analyzed for DOC concentration, absorbance, TP (total phosphorus) and sediment water content and concentration of C, N, and P were measured. In a separate experimental setup, sediment mineralization was measured in the laboratory under induced temperature changes. Sediment cores from two lakes with contrasting loadings of organic carbon were incubated in the dark at $1,3,5,8,13$ and $21{ }^{\circ} \mathrm{C}$ respectively. Sediment respiration was measured for the upper $5 \mathrm{~cm}$ layer of the sediment as DIC production. Full details are given in Methods and Supplementary Information.

\section{References}

1. Gorham, E. Northern Peatlands - Role in the carbon-cycle and probable responses to climatic warming. Ecol. Appl. 1, 182-195 (1991).

2. Emerson, S., Hedges, J. I. Processes controlling the organic carbon content of open ocean sediments. Paleoceanography 3, 621-634 (1988).

3. Dean, W. E. \& Gorham, E. Magnitude and significance of carbon burial in lakes, reservoirs, and peatlands. Geology 26, 535-538 (1998). 
4. Cole, J. J., et al. Plumbing the global carbon cycle: Integrating inland waters into the terrestrial carbon budget. Ecosystems 10, 171-184 (2007).

5. Tranvik, L. J., et al. Lakes and impoundments as regulators of carbon cycling and climate. Limnol. Oceanogr. 54, 2298-2314 (2009).

6. Battin, T. J. et al. The boundless carbon cycle. Nat. Geosci. 2, 598-600 (2009).

7. Intergovernmental Panel on Climate Change. Summary for policymakers. In Climate Change 2007: The Physical Science Basis. Contribution of Working Group I to the Fourth Assessment Report of the Intergovernmental Panel on Climate Change (eds Solomon, S. et al.) (Cambridge Univ. Press, Cambridge, 2007).

8. Mulholland, P. J. \& Elwood, J. W. The role of lake and reservoir sediments as sinks in the perturbed global carbon-cycle. Tellus 34, 490-499 (1982).

9. Stallard, R. F. Terrestrial sedimentation and the carbon cycle: Coupling weathering and erosion to carbon burial. Glob. Biogeochem. Cy. 12, 231-257 (1998).

10. Einsele, G., Yan, J. P., \& Hinderer, M. Atmospheric carbon burial in modern lake basins and its significance for the global carbon budget. Global Planet. Change 30, 167-195 (2001).

11. Downing, J. A. et al. Sediment organic carbon burial in agriculturally eutrophic impoundments over the last century. Global Biogeochem. Cy. 22, GB1018, doi:10.1029/2006GB002854 (2008).

12. Schlesinger, W. H. Evidence from chronosequence studies for a low carbon-storage potential of soils. Nature 348, 232-234 (1990).

13. Harden, J. W., Sundquist, E. T., Stallard, R. F., \& Mark, R. K. Dynamics of soil carbon during deglaciation of the Laurentide ice-sheet. Science 258, 1921-1924 (1992).

14. Trumbore, S. E. \& Harden, J. W. Accumulation and turnover of carbon in organic and mineral soils of the BOREAS northern study area. J. Geophys. Res.-Atmos. 102, 2881728830 (1997). 
15. Rapalee, G., Trumbore, S. E., Davidson, E. A., Harden, J. W., Veldhuis, H. Soil carbon stocks and their rates of accumulation and loss in a boreal forest landscape. Glob. Biogeochem. Cy. 12, 687-701 (1998).

16. Kortelainen, P. et al. Sediment respiration and lake trophic state are important predictors of large $\mathrm{CO}_{2}$ evasion from small boreal lakes. Glob. Change Biol. 12, 1554-1567 (2006).

17. Sobek, S. et al. Organic carbon burial efficiency in lake sediments controlled by oxygen exposure time and sediment source. Limnol. Oceanogr. 54, 2243-2254 (2009).

18. den Heyer, C. \& Kalff, J. Organic matter mineralization rates in sediments: A within- and among-lake study. Limnol. Oceanogr. 43, 695-705 (1998).

19. Pace, M. L., Prairie, Y. T. Respiration in lakes. In Respiration in Aquatic Ecosystems, (eds del Giorgio, P. A. and Williams, P. J. le B.) (Oxford University Press, Oxford, UK 2004).

20. Molot, L. A. \& Dillon, P. J. Storage of terrestrial carbon in boreal lake sediments and evasion to the atmosphere. Glob. Biogeochem. Cy. 10, 483-492 (1996).

21. Downing, J. A. et al. The global abundance and size distribution of lakes, ponds, and impoundments. Limnol. Oceanogr. 51, 2388-2397 (2006).

22. Benoy, G., Cash, K., McCauley, E., \& Wrona, F. Carbon dynamics in lakes of the boreal forest under a changing climate. Environ. Rev. 15, 175-189 (2007).

23. Hansen, J., Ruedy, R., Glascoe, J., \& Sato, M. GISS analysis of surface temperature change. J. Geophys. Res.-Atmos. 104, 30997-31022 (1999).

24. DeStasio, B. T., Hill, D. K., Kleinhans, J. M., Nibbelink, N. P., \& Magnuson, J. J. Potential effects of global climate change on small north-temperate lakes: Physics, fish, and plankton. Limnol. Oceanogr. 41, 1136-1149 (1996).

25. Fang, X. \& Stefan, H. G. Projections of climate change effects on water temperature characteristics of small lakes in the contiguous US. Climatic Change 42, 377-412 (1999).

26. Jankowski, T., Livingstone, D. M., Buhrer, H., Forster, R., \& Niederhauser, P. Consequences of the 2003 European heat wave for lake temperature profiles, thermal 
stability, and hypolimnetic oxygen depletion: Implications for a warmer world. Limnol. Oceanogr. 51, 815-819 (2006).

27. Wetzel, R. G., Land-water interfaces: Metabolic and limnological regulators. Verh. Internat. Verein. Limnol. 24, 6-24 (1990).

28. Girard, R. E., et al. History of chemical, physical and biological methods, sample locations and lake morphometry for the Dorset Environmental Science Centre (1973 2006). Technical Report, Ontario Ministry of the Environment Dorset, Ontario (2007). Retrieved from http://www.ene.gov.on.ca/publications/6588e.pdf

29. Persson, G. 26 svenska referenssjöar 1989 - 1993, en kemisk-biologisk statusbeskrivning Report No. 4552, Naturvårdsverket (Swedish EPA), Stockholm (1996). Retrieved from http://info1.ma.slu.se/gp/.

30. Dorrepaal, E., et al. Carbon respiration from subsurface peat accelerated by climate warming in the subarctic. Nature 460, 616-U679 (2009).

Supplementary Information accompanies the paper on www.nature.com/nature.

Acknowledgements The study was part of the research environment LEREC (Lake Ecosystem Response to Environmental Change), financially supported by FORMAS (the Swedish Research Council for Environment, Agricultural Sciences and Spatial Planning). Additional funding from VR (the Swedish Research Council) to L.J.T. and to D.B., and from FORMAS to S.S. is acknowledged.

Author contribution C.G., D.B., L.J.T, K.S., K.P. contributed to study design. C.G., D.B., S.S., K.S., K.P. contributed to sampling and analysis of data. C.G., D.B., S.S., L.J.T. wrote the paper. All authors commented on the manuscript.

Author information Reprints and permissions information is available at www.nature.com/reprints.

Correspondence and requests for materials should be addressed to C.G. (e-mail: cristian.gudasz@ebc.uu.se). 
Figure 1. Temperature dependent $\mathrm{OC}$ mineralization in lake sediments. $a$, The relationship between sediment $\mathrm{OC}$ mineralization and temperature in the present study $\left(r^{2}=0.61, P<0.0001, n=219\right)$, published literature $\left(r^{2}=0.26, P<0.0001, n=355\right)$ (Supplementary Notes) and the two combined datasets $\left(r^{2}=0.43, P<0.0001, n=574\right) ; b$, OC mineralization measured under experimental manipulation of temperature in two extreme lakes in terms of the loading of the organic carbon, the humic Svarttjärn, and the highly eutrophic Vallentunasjön ( $n=42$ for each lake). The slopes were not statistically different (t-test, $p=0.87)$. The $y$-axis of the $O C$ mineralization is represented on a log scale.

Figure 2. Mineralization and burial of $\mathrm{OC}$ in lakes. Box plots representing sediment $\mathrm{OC}$ mineralization (OCM) and average long-term net accumulation of the organic carbon in lake sediments, representing global $(G)$ and regional $(R)$ as well as individual lake/sediment core estimates (I). The boundary of the box closest to zero indicates the 25th percentile, a line within the box marks the median, and the boundary of the box farthest from zero indicates the 75th percentile. Whiskers (error bars) above and below the box indicate the 90th and 10th percentiles and symbols indicate 5th and 95th percentiles. OC mineralization data derived from the present study $(n=219)$ as well as literature data $(n=355)$. Long-term net accumulation was obtained from literature ${ }^{8,9,20}$ (Supplementary Notes). The y-axis is represented on a log scale.

Figure 3. Organic carbon burial decrease. The predicted percentage decrease in OC burial in lake sediments over the boreal zone under different climate warming scenarios by the end of the $21^{\text {st }}$ century ${ }^{7}$ : B1, A1T, B2, A1B, A2, A1F1. The symbols represent the decrease in $\mathrm{OC}$ burial based on the most likely scenarios for temperature change and the vertical bars show the response to a likely range of temperatures.

\section{Methods}

Sediment sampling and incubation. Intact sediment cores were obtained with a UWITEC sediment corer. Three replicate sediment cores were sampled in the deepest, intermediate and shallow regions. The upper $10 \mathrm{~cm}$ layer was transferred to incubation cores (54 mm inner 
diameter) without visible disturbance of the sediment structure. A floating magnetic stirring bar allowed gentle mixing of the water column above the sediment using a magnet on the outside. After the cores were filled and closed air tight and without any headspace, and before sampling, the water column was mixed with the magnet. For sampling, a mechanical system was used to press down the upper stopper of the incubation core, while simultaneously withdrawing the samples into a $50 \mathrm{ml}$ syringe, thereby avoiding the intrusion of air into the sediment incubation core. Syringes were placed immediately on ice and analyzed for DIC (dissolved inorganic carbon) concentration in the lab within few hours after sampling.

The sediment cores were incubated in situ at the sampling station in the dark. The incubation time varied between 24 and 69h. During the winter sampling occasion, the sediment cores were processed in the laboratory, and were incubated for about $140 \mathrm{~h}$ in the dark and at in situ temperatures. These incubations were carried out in special incubation chambers connected to external refrigerated/heated circulators (Julabo F25-ED). At the termination of the incubation, final water samples were taken and analyzed in a similar way as initial samples for the DIC.

DIC measurements. Measurements of the DIC (dissolved inorganic carbon) concentration were performed on a Sievers 900 TOC analyzer. The precision of the analytical method was $<1 \%$ RSD (relative standard deviation) and accuracy of $\pm 2 \%$ or $0.5 \mathrm{ppb}$ DIC.

Sediment characteristics. The upper layer of 0-5 cm was collected from three replicate cores at each station. Sub-samples were taken for C, N, P, water content and organic matter content. The sediment was dried at $105^{\circ} \mathrm{C}$. The $\mathrm{C}$ and $\mathrm{N}$ were analyzed in an elemental analyzer (NA 1500, Carlo Erba instruments). To determine sediment P content, dried sediment was ignited at 550 ${ }^{\circ} \mathrm{C}^{31}$, followed by a subsequent $\mathrm{P}$ analysis of molybdate-reactive phosphate ${ }^{32}$.

Water column characteristics. Depth profiles of temperature and oxygen concentration were measured with an OxyGuard Handy Delta oxygen meter. The concentration of TP in the water was determined accordingly ${ }^{32}$. The concentration of DOC was analyzed with a Sievers 900 TOC analyzer. 
Literature data. For literature searches we used the ISI (Web of Science) and ASFA (Aquatic Sciences and Fisheries Abstracts) databases. The published data that was considered in this study was restricted to studies carried out in undisturbed sediment cores. We collected 355 data points by digitizing of published graphs using Digitizelt 1.5.7 software. The oxygen uptake data provided in some references were converted to carbon units based on a respiratory quotient of $0.9^{33}$.

Statistical analyses. In order to consistently compare OC mineralization rates in sediments overlain by mixed (i.e., oxygenated) water, any of the data indicating anoxic conditions near the sediments were excluded from the analysis. Thus, if oxygen concentration at the layer one meter above the sediment was less than $1 \mathrm{mg} \mathrm{l}^{-1}$, incubation data was removed from the analysis. The same criterion was applied to the literature data. The contribution of other pathways of OC loss from the sediment such as $\mathrm{CH}_{4}$ or DOC release was low (Supplementary Methods).

All data analyzed by linear regression were log-transformed with the exception of ratios that were Arcsine-transformed. To compare the linear regression slopes we used the t-test approach ${ }^{34}$. We used PLS regression ${ }^{35}$ in order to find out how different variables perform as predictors of sediment respiration. Compared to ordinary multiple linear regression, PLS is useful when there are several correlated responses in the dataset, when variables deviate from normality or there is a smaller percentage of missing values. The results of a PLS analysis are displayed in the "loadings plot”, depicting the correlation structure among all factors and responses. The performance of the PLS model is expressed in the terms $R^{2} Y$ and $Q^{2} \cdot R^{2} Y$ is comparable to $R^{2}$ in linear regression, and $\mathrm{Q}^{2}$ is a measure of the predictive power of the model (the higher $\mathrm{Q}^{2}$ values, the higher the performance of the model). Variables were transformed (log for volumetric data and arcsine for ratio) prior to modelling in order to increase model performance. All PLS modelling was done on SIMCA 12.0 software (Umetrics AB, Umeå, Sweden).

The variables identified as explaining most of the variance from the PLS analysis were used in stepwise forward multiple regression model. All the variables were log-transformed in order to meet normality assumptions. Temperature data was expressed in Kelvin to avoid zero values. Other assumptions needed to meet the specification of the multiple regression analysis such as 
multicolinearity or homogeneity of the error terms were checked. The multiple regression modelling was performed in Statistica 8.0 software.

31. Andersen, J. M. An ignition method for determination of total phosphorus in lake sediments. Water Res. 10, 329-331 (1976).

32. Murphy, J., \& Riley, J. P. A modified single solution method for the determination of phosphate in natural waters. Anal. Chim. Acta. 27, 31-36 (1962).

33. Graneli, W. A comparison of carbon dioxide production and oxygen uptake in sediment cores from four south Swedish lakes. Ecography 2, 51-57 (1979).

34. Zar, J. Comparing Simple Linear Regression Equations. In Biostastistical Analysis (Prentice-Hall, Englewood Cliffs, NJ, 1984).

35. Höskuldsson, A. PLS regression methods. J. Chemometr. 2, 211-228 (1988). 

symbol, not a minus symbol. This does not affect the reported results or conclusions of the paper.
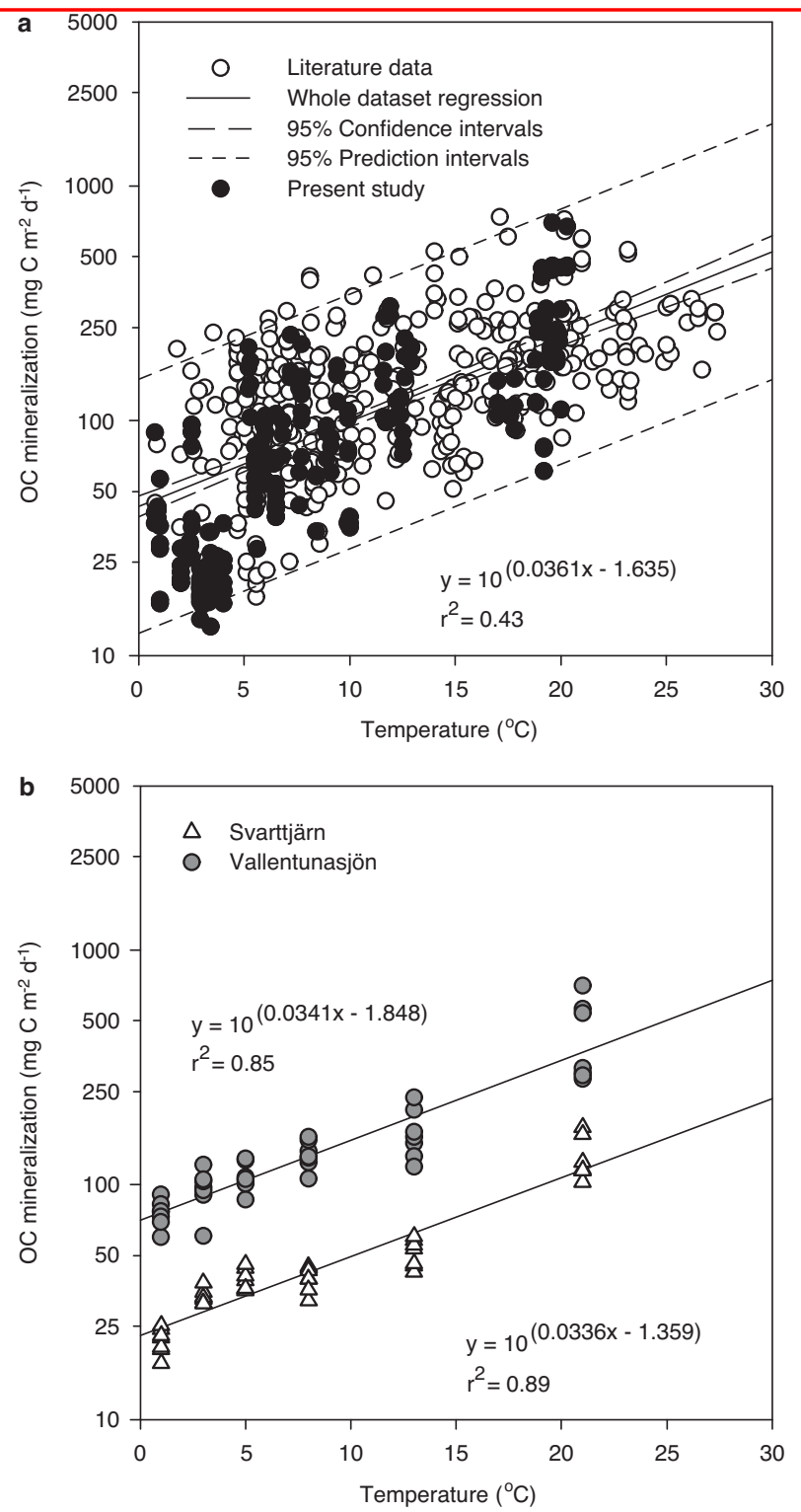


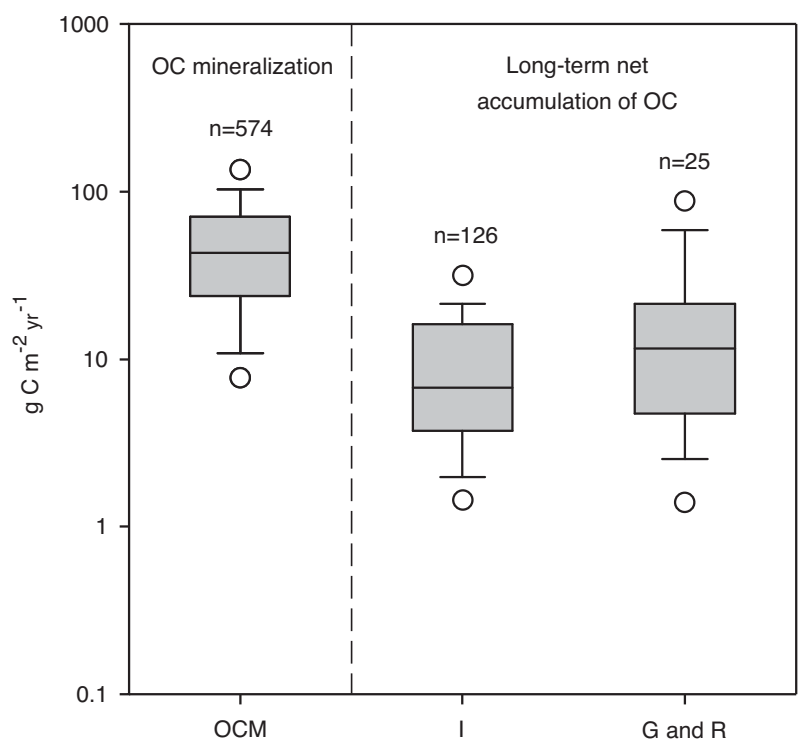




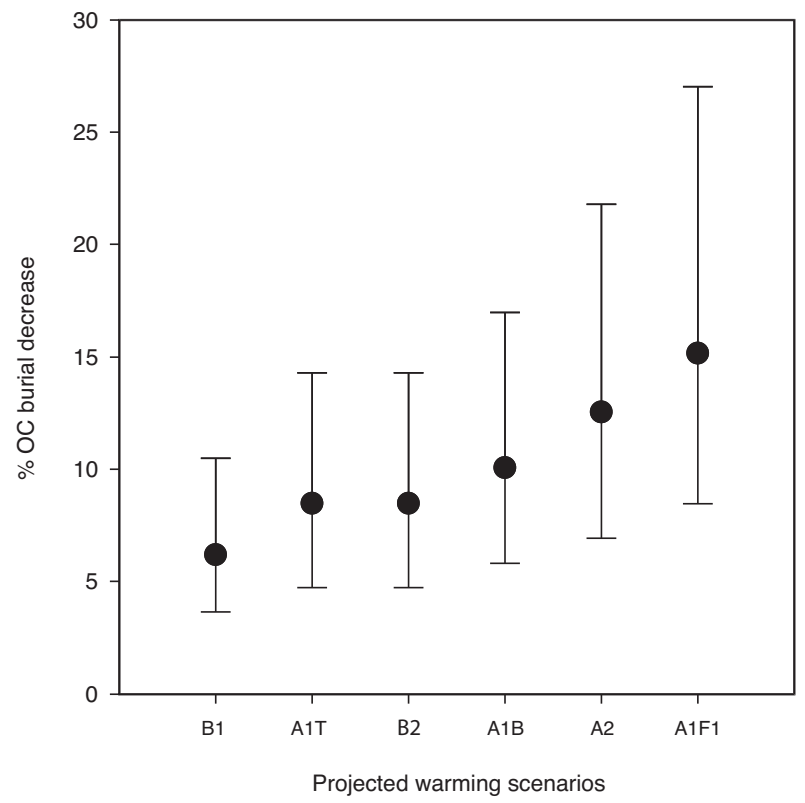




\section{Supplementary Methods}

\section{Sediment mineralization with experimentally induced temperature changes.}

Sediment mineralization was measured in two lakes with contrasting loadings of organic carbon, Svarttjärn (humic) and Vallentunasjön (highly eutrophic) respectively. DOC concentrations were similar (Svarttjärn, $27.9 \mathrm{mg} \mathrm{l}^{-1}$; Vallentunasjön, $26.2 \mathrm{mg} \mathrm{l}^{-1}$ ), but the DOC-specific absorbance at $250 \mathrm{~nm}$ (A250/DOC) differed substantially (Svarttjärn, $0.037 \mathrm{~cm}^{-1} \mathrm{mg} \mathrm{l}^{-1}$; Vallentunasjön, $0.007 \mathrm{~cm}^{-1} \mathrm{mg} \mathrm{l}^{-1}$ ), suggesting a large difference in the composition of organic matter, with Svarttjärn being highly dominated by terrestrial humic material ${ }^{36}$. The $\mathrm{C}: \mathrm{N}$ ratio (mass) of the sediment organic mater revealed similarly contrasting properties, $18.9 \pm 1.4$ for Svarttjärn and $7.95 \pm 0.09$, for Vallentunasjön ( $\mathrm{n}=6$ for both lakes).

Sediment cores sampled from the deepest point of each lake, and incubated for measurement of sediment mineralization similarly to the cross system survey. The water column of Vallentunasjön was mixed at the time of sampling and Svarttjärn was strongly stratified. The lake bottom temperature was $4.4^{\circ} \mathrm{C}$ in Svarttjärn and $20{ }^{\circ} \mathrm{C}$ on Lake Vallentunasjön. The water column above the sediment was replaced with aerated bottom lake water, and the cores were kept in six temperature-controlled water baths, equipped with a device for continuous mixing of the water column inside the incubation cores. The incubation temperatures were set to $1,3,5,8,13$ and $21^{\circ} \mathrm{C}$. At each incubation temperature and for each lake there were 7 replicate cores. The cores were incubated between 37 and 94 hours, depending on rate of mineralization, and to avoid oxygen depletion. Oxygen saturation was measured using micro-optodes (model PSt3, PreSens, Precision Sensing), and incubation time was adjusted to avoid oxygen saturation to drop below $10 \%$. DIC was measured as in the cross-system survey. 


\section{Upscaling of temperature effects on OC burial.}

To calculate the sediment mineralization for different temperature regimes, we used the temperature - sediment mineralization relationship from Fig. 1a. The mean annual air temperature in the boreal zone ranges approximately between $-5{ }^{\circ} \mathrm{C}$ and $+5{ }^{\circ} \mathrm{C}^{37}$. We considered a mean annual air temperature over the boreal biome of $0{ }^{\circ} \mathrm{C}$, and for epilimnetic sediments (i.e. sediments overlain by mixed water), we assumed an annual average temperature of $1{ }^{\circ} \mathrm{C}$. Due to the exponential relationship between OC mineralization and temperature, this assumption results in a conservative estimate of the temperature response, as $1{ }^{\circ} \mathrm{C}$ is the lowest temperature likely over lake sediments. The difference between $\mathrm{OC}$ mineralization at $1{ }^{\circ} \mathrm{C}$ and at the temperature scenarios presented by $\operatorname{IPCC}^{7}$ were used in the upscaling.

We used the long-term net accumulation of OC in boreal lakes of $19 \mathrm{~g} \mathrm{C} \mathrm{m}^{-2} \mathrm{yr}^{-1}$ ${ }^{20}$ to calculate the total amount of carbon buried in the lake sediments over the boreal zone. Considering that half of the lake area in the boreal zone is in the epilimnion, half of the total lake burial would be in the epilimnion. Due to the focusing of sediment in the deeper parts of the basin, OC burial tends to be higher in the deeper parts. To correct for this, we ran an analysis of the dynamic ratio ${ }^{38}$ and the extent of erosion and transport bottoms (ET) and of the median bottom slope in Swedish forest lakes ( $\mathrm{n}=1097$, Swedish Lake Register, the Swedish Meteorological and Hydrological Institute, data available at www.smhi.se). Based on this analyze we estimate that the ET bottoms make up on average $15 \%$ of the total lake area. Most boreal lakes have shallow basins (being situated in glaciated landscapes), resulting in epilimnetic area to a large extent being accumulation bottoms (inclination $<4 \%{ }^{38}$ ). Half of the ET areas were considered to be in the epilimnion (majority of lakes being shallow) and therefore we reduced the epilimnetic sediment area by $7.5 \%$. 
Based on the mineralization values obtained for different temperature intervals given by the IPCC scenarios ${ }^{7}$, we derived the increase in boreal epilimnetic sediment mineralization, which results in a concomitant decrease in burial in epilimnetic sediments. These numbers were then used to calculate the percentage change in total lake OC burial. The estimates of change in OC burial are conservative because the predictions based on the lower OC burial rates ${ }^{39,40}$, would result in an even greater percentage decrease of OC burial. Moreover, sediment focusing may results in a higher carbon burial in the deeper sediments. Increased epilimnetic mineralization may thus cause decreased transport of carbon to the deeper zone, and subsequently less burial.

\section{The release of $\mathrm{CH}_{4}$ and DOC from the sediment}

The release of both DOC and $\mathrm{CH}_{4}$ from sediments is greatly reduced in the presence of oxygen. Only sediments overlain by oxygenated water were studied, hence most methane was oxidized before entering the water column ${ }^{41}$. Accordingly, the measured contribution of $\mathrm{CH}_{4}$ to total sediment $\mathrm{OC}$ mineralization in our large field survey (Fig. 1) was on average $2.3 \%$ (median $0.02 \%, n=180$ ). Similarly, in oxygenated sediments DOC is to a large degree bound by Fe-III-minerals ${ }^{42,43}$ resulting in a contribution of DOC release to total C release of generally about $10 \%$ or less ${ }^{44-47}$. Hence, our data on OC mineralization cover the by far most important $\mathrm{C}$ release flux from the sediments, and probably represent a conservative estimate.

\section{Sediment temperature gradients}

The temperature gradient between water and sediment is negligible over the short distances (top 5-10 cm of sediment) covered in this study. Dividing the global mean heat flux from the Earth interior $\left(<0.1 \mathrm{~W} \mathrm{~m}^{-2}\right)$ with the potential heat flux through the sediment (molecular diffusion of water, $\sim 1.4 * 10^{-7} \mathrm{~m}^{2} \mathrm{~s}^{-1}$ times the heat capacity of water, $\sim 4.2 * 10^{6} \mathrm{~J} \mathrm{~m}^{-2}{ }^{\circ} \mathrm{C}^{-1}$ ) returns a temperature gradient in the sediment of $\sim 0.17^{\circ} \mathrm{C}$ 
$\mathrm{m}^{-1}$. This is very similar to empirical data on temperature gradients in lake sediments $\left(\sim 0.1^{\circ} \mathrm{C} \mathrm{m}^{-1} ;{ }^{48,49}\right)$. This shallow gradient also implies that the metabolically active top few $\mathrm{cm}$ of sediment adjust their temperature to the bottom water temperature within a few hours.

Supplementary Table 1 Lake area (LA), maximum depth $\left(\mathrm{Z}_{\mathrm{m}}\right)$, dissolved organic carbon (DOC) and total phosphorus (TP) concentration in the water column of lakes sampled for in situ sediment mineralization.

\begin{tabular}{lrrrr}
\hline Lake & $\mathrm{LA}(\mathrm{ha})$ & $\mathrm{Zm}(\mathrm{m})$ & $\mathrm{DOC}\left(\mathrm{mg} \mathrm{I}^{-1}\right)$ & $\mathrm{TP}\left(\mu \mathrm{I} \mathrm{I}^{-1}\right)$ \\
\hline Ljustjärn & 12 & 10 & 3.6 & 12.1 \\
Lilla Sångaren & 24 & 20 & 6.5 & 11.4 \\
Lötsjön & 63 & 10 & 12.1 & 28.1 \\
Valloxen & 290 & 6 & 18.6 & 46.7 \\
Oppsveten & 65.3 & 12 & 19.1 & 15.4 \\
Strandsjön & 130 & 3 & 20.8 & 41.3 \\
Svarttjärn & 0.7 & 6 & 28.0 & 15.1 \\
Fälaren & 205 & 2.6 & 34.3 & 20.5 \\
& & & &
\end{tabular}

\section{Supplementary Discussion}

Our data strongly suggest that the proportion of OC buried (i.e. the burial efficiency) will be reduced in a warmer climate due to a higher proportion of the sediment OC being mineralized (Fig.1). This means that even in the case of climate change-induced increases in the delivery of OC to the sediment (e.g. due to increased phytoplankton production or watershed OC export), there will not be a corresponding increase in OC 
burial, as rising temperatures will increase OC mineralization and thereby lower OC burial efficiency. In other words, future OC burial will be constrained due to temperature control of $\mathrm{OC}$ mineralization, even if the amount of $\mathrm{OC}$ delivered to the sediment may change.

The temperature effect on OC burial was estimated assuming that future rate of OC deposition on to lake bottoms is similar to the current rate. Within the boreal zone, warming affects organic matter load from primary production and import from the watershed widely different among regions, depending on different trajectories of precipitation. For example, while watershed OC export has decreased in parts of the Canadian boreal zone $e^{50,51}$, it has increased in some, but not all parts of Scandinavia ${ }^{52,53}$ potentially resulting in concomitant changes in $\mathrm{C}$ delivery to the sediments ${ }^{54}$. The robust relationship between temperature and OC mineralization (Fig. 1) provides strong evidence that the OC sink in lake sediments of the boreal zone will be weakened, even if climate change-induced changes in OC delivery to the sediment may work against the temperature effect in some areas, but amplify it in other areas.

Temperature changes affect the mineralization of sediments that have accumulated over several years or decades. The OC mineralization in such older, sediment layers contribute $\sim 10-60 \%$ to total sediment OC mineralization ${ }^{55,56}$. This further decouples our conclusion of temperature-controlled OC burial from potential changes in future OC delivery to the sediments, and suggests that future warming may result in the mobilization of carbon that was deposited in the past.

Since the relationship between temperature and OC mineralization was similar across a wide range of different lake sediments (Fig. 1), covering great differences in the amount and quality of OC delivery to the sediment, it is applicable to lake sediments in general, hence enabling us to generate the first biome-wide estimate of how a warmer climate affects lake OC burial. 


\section{Supplementary Notes}

\section{References for Supplementary Methods and Supplementary Discussion}

36. McKnight, D. M., \& Aiken, G. R. Sources and age of aquatic humus. In Aquatic Humic Substances. (eds Hessen, D. O. \& Tranvik, L. J.) (SpringerVerlag, Berlin Heidelberg, 1998).

37. Whittaker, R. H. 1975. Communities and Ecosystems, $2^{\text {nd }}$ ed.

38. Håkanson, L. A Manual of Lake Morphometry. (Springer-Verlang, Berlin, Heidelberg, New York, 1981).

39. Campbell, I. D. et al. A first estimate of organic carbon storage in Holocene lake sediments in Alberta, Canada. J. Paleolimn. 24, 395-400 (2000).

40. Kortelainen, P., Pajunen, H., Rantakari, M., \& Saarnisto, M. A large carbon pool and small sink in boreal Holocene lake sediments. Glob. Change Biol. 10, 1648-1653 (2004).

41. Bastviken, D., Methane in Encyclopedia of Inland Waters, edited by Gene E. Likens (Elsevier, Oxford, 2009), Vol. 2, pp. 783-805.

42. O'Loughlin, E.J. \& Chin, Y.P., Quantification and characterization of dissolved organic carbon and iron in sedimentary porewater from Green Bay, WI, USA. Biogeochemistry 71, 371-386 (2004).

43. Skoog, A.C. \& Arias-Esquivel, V.A., The effect of induced anoxia and reoxygenation on benthic fluxes of organic carbon, phosphate, iron, and manganese. Sci. Total Environ. 407, 6085-6092 (2009). 
44. Klump, J.V., Fitzgerald, S.A., \& Waples, J.T., Benthic biogeochemical cycling, nutrient stoichiometry, and carbon and nitrogen mass balances in a eutrophic freshwater bay. Limnol. Oceanogr. 54, 692-712 (2009).

45. Burdige, D.J. \& Homstead, J., Fluxes of Dissolved Organic-Carbon from Chesapeake Bay Sediments. Geochim. Cosmochim. Ac. 58, 3407-3424 (1994).

46. Otto, S. \& Balzer, W., Release of dissolved organic carbon (DOC) from sediments of the NW European Continental Margin (Goban Spur) and its significance for benthic carbon cycling. Progr. Oceanogr. 42, 127-144 (1998)

47. Gale, P.M. \& Reddy, K.R., Carbon Flux between Sediment and Water Column of a Shallow, Subtropical, Hypereutrophic Lake. J. Environ. Qual. 23, 965-972 (1994).

48. Pugh, D.T., Geothermal Gradients in British Lake-Sediments. Limnol. Oceanogr. 22, 581-596 (1977).

49. Duchkov, A.D., Kazantsev, S.A., \& Duchkov, A.A., Bottom temperature monitoring in Lake Baikal. Russ. Geol. Geophy. 48, 371-377 (2007).

50. Schindler, D.W. et al., The effects of climatic warming on the properties of boreal lakes and streams at the Experimental Lakes Area, northwestern Ontario. Limnol. Oceanogr. 41, 1004-1017 (1996).

51. Schindler, D.W. et al., Climate-induced changes in the dissolved organic carbon budgets of boreal lakes. Biogeochemistry 36, 9-28 (1997).

52. Tranvik, L. J. \& Jansson, M., Climate change - Terrestrial export of organic carbon. Nature 415 (6874), 861-862 (2002). 
53. Monteith, D.T. et al., Dissolved organic carbon trends resulting from changes in atmospheric deposition chemistry. Nature 450 (7169), 537-U539 (2007)

54. von Wachenfeldt, E. \& Tranvik, L., Sedimentation in Boreal Lakes-The Role of Flocculation of Allochthonous Dissolved Organic Matter in the Water Column. Ecosystems 11, 803-814 (2008).

55. Maerki, M., Muller, B., \& Wehrli, B., Microscale mineralization pathways in surface sediments: A chemical sensor study in Lake Baikal. Limnol. Oceanogr. 51, 1342-1354 (2006).

56. Maerki, M., Muller, B., Dinkel, C., \& Wehrli, B., Mineralization pathways in lake sediments with different oxygen and organic carbon supply. Limnol. Oceanogr. 54, 428-438 (2009).

\section{References for data in Figure 1}

57. Hargrave, B. T. Epibenthic algal production and community respiration in sediments of Marion Lake. J. Fish. Res. Board Can. 26, 2003-2026 (1969).

58. Provini, A. 1975. Sediment respiration in six Italian lakes in different trophic conditions. Verh. Internat. Verein. Limnol. 19, 1313-1318 (1975).

59. Graneli, W. Sediment oxygen-uptake in south Swedish lakes. Oikos 30, 7-16 (1978).

60. Graneli, W. A comparison of carbon dioxide production and oxygen uptake in sediment cores from four south Swedish lakes. Ecography 2, 51-57 (1979).

61. Jensen, H. S., \& Andersen, F. Ø. Importance of temperature, nitrate, and pH for phosphate release from aerobic sediments of 4 shallow, eutrophic lakes. Limnol. Oceanogr. 37, 577-589 (1992). 
62. Ramlal, P. S., Kelly, C. A., Rudd, J. W. M., \& Furutani, A. Sites of methyl mercury production in remote Canadian shield lakes. Can. J. Fish. Aquat. Sci. 50, 972-979 (1993).

63. Liikanen, A., Murtoniemi, T., Tanskanen, H., Vaisanen, T., \& Martikainen, P. J. Effects of temperature and oxygen availability on greenhouse gas and nutrient dynamics in sediment of a eutrophic mid-boreal lake. Biogeochemistry 59, 269286 (2002).

\section{References for data in Figure 2}

64. Alin, S. R., \& Johnson, T. C. Carbon cycling in large lakes of the world: A synthesis of production, burial, and lake-atmosphere exchange estimates. Glob. Biogeochem. Cy. 21, GB3002, doi:10.1029/2006GB002881 (2007).

65. Boville, B. W., Munn, R. E., Hare, F. K. The storage of non-living organic carbon in boreal and arctic zones-Canada. Final report, Department of Energy, Washington, DC, (DE-AS01-81EV-10688) (1983).

66. Campbell, I. D. et al. A first estimate of organic carbon storage in Holocene lake sediments in Alberta, Canada. J. Paleolimnol. 24, 395-400 (2000).

67. Dean, W. E. \& Gorham, E. Magnitude and significance of carbon burial in lakes, reservoirs, and peatlands. Geology 26, 535-538 (1998).

68. Einsele, G., Yan, J. P., \& Hinderer, M. Atmospheric carbon burial in modern lake basins and its significance for the global carbon budget. Global Planet. Change 30, 167-195 (2001).

69. Jonsson, A., \& Jansson, M. Sedimentation and mineralisation of organic carbon, nitrogen and phosphorus in a large humic lake, northern Sweden. Arch. Hydrobiol. 141, 45-65 (1997). 
70. Kortelainen, P., Pajunen, H., Rantakari, M. \& Saarnisto, M. A large carbon pool and small sink in boreal Holocene lake sediments. Glob. Change Biol. 10, 16481653 (2004).

71. Pajunen, H. 2000. Lake sediments: Their carbon store and related accumulation rates. Geological Survey of Finland, Special Paper 29: 39-69.

72. Sobek, S., Söderbäck B., Karlsson S., Andersson E., Brunberg A.-K. 2006. A carbon budget of a small humic lake: An example of the importance of lakes for organic matter cycling in boreal catchments. Ambio 35: 468-475.

References regarding sediment mineralization data used in Figure 2 are the same as in Figure 1. 